\title{
Factors Affecting Nutritional Status in Children Aged 6-24 months in Lamongan Regency, Indonesia
}

\author{
Abdul Aziz Alimul Hidayat ${ }^{1 *}$, Gita Marini ${ }^{1}$, Anaestasia Pangestu Mei Tyas ${ }^{2}$ \\ ${ }^{1}$ Departement of Nursing, Faculty of Health Sciences, University of Muhammadiyah Surabaya, Indonesia; ${ }^{2}$ Departement of \\ Nursing, Airlangga University, Surabaya, Indonesia
}

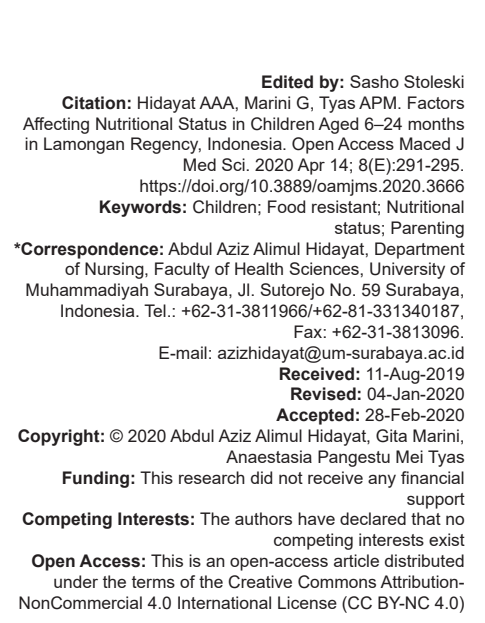

\section{Abstract}

BACKGROUND: Family food security and parenting are factors affecting changes in nutritional status related to family care and food availability.

AIM: This study aims to analyze the factors affecting nutritional status in children aged 6-24 months in Lamongan Regency, Indonesia.

METHODS: The study used cross-sectional data with 191 children aged 6-24 months and their parents, selected by simple random sampling. The data were collected through observations and interviews and used to assess the physical endurance and nutritional status based on the questionnaires, food frequency, observations, weight scales, and World Health Organization/National Center for Health Statistics reference standards.

RESULTS: The results of the double linear regression test $p=0.000$ indicated that the parenting coefficient had more influence on the nutritional status of children aged 6-24 months than the family food security coefficient on the nutritional status of children in Lamongan Regency, with $\mathrm{Y}=1.565+0.062 \mathrm{X} 1+0.446 \mathrm{X} 2$, $\mathrm{Y}$ being nutritional status, 1.565 as the coefficient value, $\mathrm{X} 1(0.062)$ being family food security, and $\mathrm{X} 2(0.446)$, parenting

CONCLUSION: Better parenting improved the nutritional status of children aged 6-24 months compared to maintaining food security. Thus, parenting improvement programs could be prioritized through the Community Health Center

\section{Introduction}

Poor nutrition is still a public health problem in Indonesia according to nutritional monitoring data (PSG 2016) from the Institution of the Directorate General of Community Nutrition Directorate General of Public Health Ministry of Health of the Republic of Indonesia. As many as, $3.4 \%$ of children under 5 years old have poor nutrition (especially aged 6-24 months). About 13.9\% of children in the province of East Java under the age of 5 years (especially aged 6-24 months) also experience malnutrition. Since this age is when brain development will reach $80 \%$, malnutrition risks slowing down growth and development [1]. The problem of malnutrition is also experienced by children in Lamongan Regency, a district of East Java.

Poor nutrition can be caused by several factors, such as children's food (diet), infectious diseases, family food security, childcare patterns, health services, and environmental health. Two factors, namely, food security and parenting, are currently the main concerns of the Lamongan Regency government. Children's nutritional status is influenced by various factors related to food security such as physical dimensions (availability), the economy (purchasing power), nutrition (fulfillment of needs), individual cultural and religious values, food security (health), and time (continuous availability).

Parenting factors can also affect nutritional status, since they may determine children's feeding patterns and families' eating habits. These two factors have been studied extensively. Fatimah et al. (2012) stated that there is a strong relationship between these factors and the nutritional status of children in rural areas [2]. Rusyantia et al. (2017) stated that food security could improve people's nutritional status [3]. Handayani (2017) stated that parenting affects children's nutritional status [4]. Aramico et al. (2016) stated that parenting affects the nutritional status of school-age children in one of the districts in Aceh [5].

These studies and others, however, have not researched how these factors influence malnutrition, especially in children aged $<5$ years. This study analyzes the factors influencing the nutritional status of children aged 6-24 months who live in Lamongan Regency, Indonesia. 


\section{Methods}

This study consisted of cross-sectional research involving 191 children aged 6-24 months and their parents. The sampling technique used was simple random sampling to select the respondents. The data were collected from participants who met the following criteria: (1) Children aged 6-24 months from families living in Lamongan Regency, (2) children who were free of other diseases (chronic disease) besides malnutrition, and (3) parents who were willing to be studied.

The data were collected through a questionnaire about parenting and food security. The food security questionnaire consisted of three questions about the availability of rice for $>120$ days, frequency of eating more than 3 times a day, and protein consumption. The food security questionnaire used several food security indicators such as food availability, namely, the availability of rice for $\geq 120$ days, having money to buy rice for $\geq 120$ days, sustainability measured by the frequency of food consumption, and food security measured by access to food containing animal and vegetable protein, which was ranked first. The third category entails stable food supply and good consumption of protein (able to afford both animal and vegetable protein). The questionnaire calculated food security based on food security indicators as in the reference [6] and nutritional status using weight measurements based on the age.

The parenting questionnaire used indicators such as frequency, type of food, and feeding methods, and categorized parents into (1) less parenting, (2) sufficient parenting, and (3) good parenting [7].

The nutritional status data were measured using the anthropometry index of body weight/age and categorized according to the National Center for Health Statistics classification. The categories are (1) weight very low (poor nutrition) if <-3 standard deviations (SD); (2) weight - low (lack of nutrition) if $\geq-3 \mathrm{SD}$ and $<-2 \mathrm{SD}$; (3) weight - normal (good nutrition) if $\geq-2$ SD and $<+2$ SD; and (4) weight - more (more nutrition) if $>+2$ SD [8].

All of the data were loaded into the Statistical Package for the Social Sciences version 19 and analyzed using statistical methods. Multiple linear regressions were used to analyze the factors influencing nutritional status of children aged 6-24 months. The level of significance was set at $p<0.05$.

\section{Results}

Table 1 shows that most age of mothers were 25-29 years $(47.6 \%)$, most of them were farmers
$(40.8 \%)$, the most common number of family members was more than four $(53.9 \%)$, most children were female $(77.5 \%)$, and the average age of children was 15.28 months.

Table 1: Distribution of respondents by age, occupation of parents, number of family members, sex of children, and age of children in Lamongan Regency 2018

\begin{tabular}{lll}
\hline Characteristics of respondents & Frequency & Percentage \\
\hline Age of mother & 25 & \\
20-24 years & 91 & 13.1 \\
25-29 years & 47 & 47.6 \\
30-34 years & 11 & 24.6 \\
35-39 years & 10 & 5.8 \\
40-44 years & 5 & 5.2 \\
45-49 years & - & 2.6 \\
50-54 years & 1 & - \\
55-59 years & 1 & 0.5 \\
60-64 years & & 0.5 \\
Parents' job & 51 & 6.7 \\
Farm workers & 78 & 40.8 \\
Farmer & 53 & 27.7 \\
Private/self-employed & 5 & 2.6 \\
Government employees & 4 & 2.1 \\
Not working/housewife & & \\
Number of family members & 88 & 46.1 \\
s4 & 103 & 53.9 \\
$>4$ & & 22.5 \\
Child sex & 43 & 77.5 \\
$\quad$ Male & 148 & $\mathrm{SD}$ \\
Female & Mean & 4.50 \\
\hline$\quad$ Age of child (months) & 16.28 & \\
\hline
\end{tabular}

Table 2 shows that almost half of the respondents had food-resistant households (48.2\%). In terms of parenting, most were classified as good parenting (52.2\%). In terms of nutritional status, most children had normal body weight (78.0\%).

Table 2: Status of family food security, parenting, and nutritional status of children aged 6-24 months in Lamongan Regency, 2018

\begin{tabular}{lll}
\hline Variable & Frequency & Percentage \\
\hline Food security & & \\
$\quad$ Households are not food-resistant & 43 & 22.5 \\
$\quad$ Households lack food security & 56 & 29.3 \\
$\quad$ Food-resistant households & 92 & 48.2 \\
Parenting & & \\
$\quad$ Less & 31 & 16.2 \\
Medium & 60 & 31.4 \\
$\quad$ Fine & 100 & 52.4 \\
Nutritional status & & \\
$\quad$ Body weight is very low & 6 & 3.1 \\
Low weight & 35 & 18.3 \\
Normal weight & 149 & 78.0 \\
Above normal & 1 & 0.5 \\
\hline
\end{tabular}

Table 3 shows that the effects of food security and parenting on improving nutritional status. The results of the double linear regression test $(p=0.000)$ indicate that the coefficient of parenting had more influence on the nutritional status of children aged 6-24 months than the family food security coefficient because the parenting coefficient was higher than the family food security coefficient, $Y=1.565+0.062 \times 1+$ $0.446 \mathrm{X} 2$, with $\mathrm{Y}$ being nutritional status, 1.565 being the coefficient value, and $X 1(0.062)$ being family food security and X2 (0.446), parenting. As per Table 4, the $R$ value of 0.746 shows that family food security variables and parenting have a very strong relationship with nutritional status variables, since the value of $R$ measures the correlation of coefficients. If the value is closer to -1 or 1 , the relationship is getting stronger. If the value is closer to 0 , the relationship is getting weaker. The $\mathrm{R}^{2}$ value (coefficient of determination) 
Table 3: Effect of family food resilience and fostering patterns on nutritional status of children aged 6-24 months in Lamongan Regency

\begin{tabular}{|c|c|c|c|c|c|c|c|c|}
\hline \multirow[t]{3}{*}{ Variable } & \multicolumn{8}{|c|}{ Nutritional status } \\
\hline & \multicolumn{2}{|c|}{ Body weight is very low } & \multicolumn{2}{|c|}{ Low weight } & \multicolumn{2}{|c|}{ Normal weight } & \multicolumn{2}{|c|}{ More weight } \\
\hline & $\mathrm{n}$ & $\%$ & $\mathrm{n}$ & $\%$ & $\mathrm{n}$ & $\%$ & $\mathrm{n}$ & $\%$ \\
\hline \multicolumn{9}{|l|}{ Family food security } \\
\hline $\begin{array}{l}\text { Households are not } \\
\text { food-resistant }\end{array}$ & 5 & 2.60 & 32 & 16.80 & 6 & 3.10 & 0 & 0.00 \\
\hline Households lack food security & 0 & 0.00 & 3 & 1.60 & 53 & 27.70 & 0 & 0.00 \\
\hline Food-resistant & 1 & 0.50 & 0 & 0.00 & 90 & 47.10 & 1 & 0.50 \\
\hline \multicolumn{9}{|l|}{ Parenting } \\
\hline Less & 5 & 2.60 & 26 & 13.60 & 0 & 0.00 & 0 & 0.00 \\
\hline Medium & 1 & 0.50 & 9 & 4.70 & 50 & 26.20 & 0 & 0.00 \\
\hline Good & 0 & 0.00 & 0 & 0.00 & 99 & 51.80 & 1 & 0.50 \\
\hline
\end{tabular}

of $0.556(55.6 \%)$ is close to $1(100 \%)$, which means that the model is good because the variables (family food security and parenting) can explain the nutritional status variables. The null hypothesis is rejected, since $p=0.000$. This implies that the variables of family food security and parenting affected the nutritional status variable.

Table 4: Factors influencing nutritional status in children aged 6-24 months in Lamongan Regency $(n=191)$

\begin{tabular}{llllll}
\hline Model & \multicolumn{2}{l}{ Unstandardized coefficients } & $\begin{array}{l}\text { Standardized } \\
\text { coefficients }\end{array}$ & $\mathrm{t}$ & \multirow{2}{*}{ Sig. } \\
\cline { 2 - 4 } & $\mathrm{B}$ & Standard error & Beta & & \\
\hline (Constant) & 1.565 & 0.082 & & 19.158 & 0.000 \\
Family food security & 0.062 & 0.067 & 0.098 & 0.927 & 0.035 \\
Parenting & 0.446 & 0.072 & 0.657 & 6.192 & 0.000 \\
\hline R=0.746; Adjusted $R^{2}=0.556$. & & & &
\end{tabular}

\section{Discussion}

The coefficients show that parenting had more influence on the nutritional status of children aged 6-24 months in Lamongan Regency than family food security because parenting's coefficient was higher than that of family food security.

The previous studies show malnutrition status (nutrition status) of children in Indonesia mostly caused by nutritional intake factor and protein insufficiency [9]; moreover, family income and education also become factor of children malnutrition which is mostly related to the factor of malnutrition in Indonesia $(O R=2,713)$ [10]. This previous study clarified that education factor is vividly related to parenting factor and food security factor is highly related to family income factor, thus it can broaden the previous studies that malnutrition status in Indonesia is not merely caused by nutritional intake factor and protein insufficiency but caused by family income and lack of education factor, also it is also affected by parenting and family food security factor in family.

This study implies that parenting is more influential on nutritional status than family food security. Better nutritional status cannot be achieved if parental/ caregiver care for the child is lacking, even if the family is food-resistant [11], [12], [13], [14]. Parenting here entails providing children with love and attention that can improve the psychological quality and independence of toddlers, contributing to their growth and development. Meanwhile, families that are not food-resistant may experience problems in providing adequate food for children [15], [16], [17], [18].

The results show that a small percentage of respondents was food-resistant with very low body weight due to congenital heart abnormalities. Their malnutrition was not caused by a lack of food but by congenital heart disease, which causes lack of appetite and weakens children's immune systems. Payne (1983) stated that health status (nutritional status) is influenced by factors such as environment, behavior, health services, and heredity, as per the theory of healthy sickness [19]. Green et al. (1980) stated that behavior (diet) is influenced by three main factors, namely, the predisposing factor, enabling factor (family food security), and reinforcing factor. Thus, family food security and parenting indirectly affect nutritional status [15], [20].

Families with food security are able to provide enough food for their children without experiencing food shortages. Families who are not food-resistant may experience problems in providing adequate food for their children. Parenting entails making sure that a family gets enough high-quality food and nutrition, especially the children, who are not able to fend for themselves. Observing proper feeding patterns also helps to improve the nutritional status of children [21], [22].

In terms of food availability and sustainability, the children received sufficient food/energy from consuming a staple food (rice) for $\geq 120$ days and eating 3 times a day. For animal protein, almost half of the respondents consumed chicken eggs daily, and for vegetable protein, almost all respondents consumed tofu and tempeh daily. Vegetable sources such as tofu and tempeh can be consumed by all the households in villages in the district because their prices are relatively cheap and they are easily available. Chicken eggs are consumed as a source of animal protein because they are affordable. Families', especially the children's, need for protein are being met by consuming chicken eggs, tofu, and tempeh [23].

This is in accordance with the physiological and psychological needs of both children and parents. The act of feeding children meets the following needs: (a) Physiological, namely, nutritional needs for metabolic processes, activities, and children's development; (b) 
psychological, namely, to satisfy children by providing other pleasures; and (c) educational, namely, educating babies and children on how to consume food, to foster good eating habits and behavior so that they will choose proper foods in line with their parents' beliefs or religion [16].

Based on this study result, it has a significant role in affecting malnutrition in Lamongan in which it is not only merely parenting factor but also caused by environment and social factor in Lamongan society. This is related to the lack of knowledge and education, also the society and family culture result the eldest member in the family (grandparents) still hold a significant role in making decision of food feeding or parenting. Thus, parenting factor becomes more essential than food security factor in affecting malnutrition.

\section{Conclusion}

The purpose of this study was to determine the factors influencing the nutritional status of children aged 6-24 months in Lamongan Regency, Indonesia. The factors tested were food security and parenting. The results show that parenting was more influential in improving the nutritional status of children aged 6-24 months in Lamongan Regency, with a higher coefficient than family food security.

\section{Acknowledgments}

The authors would like to thank Muhammadiyah University of Surabaya for facilitating this research.

\section{References}

1. Kemenkes. Hasil Pemantauan Status Gizi (PSG) dan Penjelasannya Tahun 2016. Jakarta: Kementerian Kesehatan Republk Indoenesia; 2016.

2. Fatimah MK, Pangestuti R, Dina MG, Natalia LD. Relationship family level food security and adequacy levels of substances nutrition with toddler's nutritional status in the gondangwinangun village year 2012. J Kesehatan Masyarakat Univ Diponegoro. 2013;2:1-18. https://doi.org/10.20473/amnt.v3i4.2019.201-211

3. Rusyantia A, Haryono D, Kasymir E. Study of food security rural households in an effort to increase their status community nutrition in South Lampung Regency. J Penelitian Pertanian Terapan. 2017;10(3):171-84. https://doi.org/10.25182/ jgp.2008.3.3.185-191

4. Handayani R. Factors related to status nutrition in children under five. J Endurance. 2017;2(2): 217-24. https://doi.org/10.22216/ jen.v2i2.1742

5. Aramico B, Sudargo T, Susilo J. Socioeconomic relations parenting, eating patterns with stunting in elementary school students in Lut Tawar District, Central Aceh District. J Gizi Dietetik Indone. 2016;1(3):121-30. https://doi.org/10.21927/ ijnd.2013.1(3).121-130

6. Narendra MB, Sularyo TS, Soetjiningsih SS, Ranuh I, Wiradisuria S. Tumbuh Kembang anak dan Remaja. Jakarta: Sagung Seto; 2002.

7. Etikawati AI, Siregar JR, Jatnika R, Widjaja H. Development Javanese culture value-based parenting instruments. J IImu Keluarga. 2019;12(3):208-22. https://doi.org/10.24156/ jikk.2019.12.3.208

8. World Health Organization. WHO Multicentre Growth Reference Study Group: WHO Child Growth Standards: Length/Heightfor-Age, Weight-for-Age, Weight-for-Length, Weight-for-Height and Body Mass Index-for-age: Methods and Development. Geneva: World Health Organization; 2006. https://doi. org/10.1111/j.1651-2227.2006.tb02378.x

9. Dwiyanti D, Hadi H, Susetyowati S. Effect of food intake on the incidence of malnutrition in the hospital. J Gizi Klinik Indonesia. 2003;1(1):1-7. https://doi.org/10.22146/ijcn.15354

10. Gandini AL, Kalsum $U$, Sutrisno. Factors that influence the event of malnutrition in children. MNJ Nurs J. 2017;1(2):90-8. http://dx.doi.org/10.35963/mnj.v2i6

11. Oliveira LB, Sheiham A, Bönecker M. Exploring the association of dental caries with social factors and nutritional status in Brazilian preschool children. Eur J Oral Sci. 2008;116(1):37-43. https://doi.org/10.1111/j.1600-0722.2007.00507.x PMid: 18186730

12. Zaini MA, Lim C, Low W, Harun F. Factors affecting nutritional status of Malaysian primary school children. Asia Pac J Public Health. 2005;17(2):71-80. https://doi.org/10.1177/101053950501700203 PMid:16425649

13. Mittal A, Singh J, Ahluwalia S. Effect of maternal factors on nutritional status of 1-5-year-old children in urban slum population. Indian J Community Med. 2007;32(4):264. https:// doi.org/10.4103/0970-0218.37691

14. Castel H, Shahar D, Harman-Boehm I. Gender differences in factors associated with nutritional status of older medical patients. J Am Coll Nutr. 2006;25(2):128-34. PMid:16582029

15. Hidayat AA, Prasetyo E. Predictors of malnutrition in children aged less than 5 years in Surabaya, Indonesia. Pak J Nutr. 2018;17(12):641-6. https://doi.org/10.3923/pjn.2018.641.646

16. Hidayat AA, Uliyah $M$. The self-care learning exchange (Scle) model: A model for promoting nutrition in malnourished children in indonesia. Indian J Public Health Res Dev. 2018;9(10):30611. https://doi.org/10.5958/0976-5506.2018.01361.x

17. Caballero B, Rubinstein S. Environmental factors affecting nutritional status in urban areas of developing countries. Arch Latinoam Nutr. 1997;47(2 Suppl 1):3-8. PMid:9659409

18. Arimond M, Ruel MT. Dietary diversity is associated with child nutritional status: Evidence from 11 demographic and health surveys. J Nutr. 2004;134(10):2579-85. https://doi.org/10.1093/ jn/134.10.2579

PMid:15465751

19. Payne L. Health: A basic concept in nursing theory. J Adv Nurs. 1983;8(5):393-5.

20. Green LW, Ottoson JM, García C, Hiatt RA, Roditis ML. Diffusion theory and knowledge dissemination, utilization and integration. Front Public Health Serv Syst Res. 2014;3(1):3.

PMid:26251771 
21. Arlius A, Sudargo T, Subejo S. Relationship of food security families with under five nutritional status (study in Palasari village and the Puskesmas sub-district of Legok, Tangerang Regency). J Ketahanan Nasional. 2017;23(3):359-75. https:// doi. org/10.22146/jkn.25500

22. Hidayat AA, Uliyah $M$. The effect of the nursing care model based on culture to improve the care of malnourished madurese children in Indonesia. Open Access Maced J Med Sci. 2019;7(7):1220-5. https://doi.org/10.3889/oamjms.2019.260

23. Hidayat $A A$, Uliyah $M$. Analysis of nursing diagnosis using an expert system in paediatric patients. Int J Civil Eng Tech. 2018;9(8):17-26. 